\title{
PENGARUH REWARD DAN PUNISHMENT TERHADAP KINERJA PEGAWAI
}

\author{
Evi Sofiati \\ International Women University \\ evi.sofiati3@gmail.com
}

\begin{abstract}
Abstrak - Tujuan penelitian ini adalah untuk mengetahui dan menganalisis: (1) Reward (2) Punishment; (3) Kinerja Pegawai; serta (4) Pengaruh Reward dan Punishment terhadap Kinerja Pegawai di Madrasah Ibtidaiyah Sains Baiturrahman Jatinangor, baik secara simultan maupun parsial. Metode penelitian yang digunakan dalam penelitian ini adalah survei deskriptif dan survei eksplanatori, unit analisis dalam penelitian ini adalah para staf di lingkungan pegawai Madrasah Ibtidaiyah Sains Baiturrahman Jatinangor dengan sampel sebanyak 30 orang. Tipe investigasinya adalah causalitas, serta time horizon dalam penelitian ini adalah cross-sectional. Berdasarkan hasil penelitian, diperoleh bahwa Reward pada pegawai Madrasah Ibtidaiyah Sains Baiturrahman Jatinangor ternyata pegawai memberikan tanggapan baik, Punishment pada pegawai Madrasah Ibtidaiyah Sains Baiturrahman Jatinangor pada umumnya dapat dikatakan baik, kinerja pegawai pada Madrasah Ibtidaiyah Sains Baiturrahman Jatinangor saat ini dinilai baik. Reward dan Punishment secara simultan berpengaruh terhadap kinerja pegawai Madrasah Ibtidaiyah Sains Baiturrahman Jatinangor. Namun secara parsial Reward dominan mempengaruhi kinerja pegawai daripada Punishment. Karena Reward lebih dominan mempengaruhi kinerja pegawai, menjadi prioritas pertama dalam meningkatkan kinerja pegawai. maka Madrasah Ibtidaiyah Sains Baiturrahman Jatinangor disarankan untuk tetap konsisten mempertahankan sistem reward yang ada, sehingga pegawai mampu bekerja lebih profesional
\end{abstract}

\section{Kata Kunci : Reward, Punishment, dan Kinerja}

Abstract - The purpose of this study was to determine and analyze : (1) Reward, (2) Punishment, (3) Employee Performance, and (4) The Effect of Reward and Punishment on the performance of employees in the Islamic Elementary Science School Baiturrahman Jatinangor, both simultaneously and partially. The research method used in this study is a descriptive survey and an explanatory survey, the unit of analysis in this study is the staff in the Islamic Elementary Science environment Baiturrahman Jatinangor with a sample of 30 people. The type of investigation is causality and time horizon in this study is croos-sectional. Based on the results of the study, it was found that the reward of the Islamic Elementary Science School Baiturrahman Jatinangor employees turned out to give good responses, Punishment for Islamic Elementary Science School Baiturrahman Jatinangor employees in general can be said to be good, Employee performance of Islamic Elementary Science School Baiturrahman Jatinangor this time rated good. Simultaneously Reward and Punishment affect the performance of Islamic Elementary Science School Baiturrahman Jatinangor employees. But partially, the dominant reward influences employee performance rather than punishment. Becauce Reward are more dominant 
in influencing employee performance, it is the first priority inimproving employeeperformance then Islamic Elementary Science School Baiturrahman Jatinangor is advised to remain consistent in maintaining the existing reward system, so that employees are able to work more professionally.

\section{Keywords : Reward, Punishment, and Performance}

\section{PENDAHULUAN}

Manajemen sumber daya manusia merupakan sebuah rencana, kegiatan yang bertujuan untuk memperoleh, mengembangkan, memelihara, dan menggunakan sumber daya manusia guna membantu perusahaan untuk mencapai tujuannya. Dalam pencapaian tujuan perusahaan membutuhkan sumber daya manusia (karyawan) yang berkualitas, salah satu cara peningkatan kualitas diri dari setiap karyawan adalah dengan memberikan reward and punishment.

Dalam upaya peningkatan kinerja, organisasi perlu fokus kepada komponen pemenuhan kebutuhan karyawan. Reward digunakan sebagai salah satu langkan untuk pemenuhan kebutuhan karyawan guna mencapai titik kualitas diri yang terbaik. Penggunaan reward sejatinya akan menjadi acuan bagi karyawan untuk meningkatkan skill dan juga pengembangan diri, sehingga laju peningkatan kinerja akan berpengaruh kepada perusahaan. Penghargaan melalui sistem manajemen gaji merupakan salah satu penghargaan yang paling inti atas kinerja yang dilakukan oleh karyawan dalam hitungan bulan, atau mingguan. Artinya capaian kerja yang mereka lakukan dibalas setimpal melalui sistem pengajian oleh perusahaan. Sehingga karyawan akan lebih termotivasi untuk mendapatkan kembali penghargaan tersebut dalam minggu ataupun bulan selanjutnya. Sesuai dengan Prinsip sistem manajemen gaji adalah bahwa kinerja yang luar biasa harus diberi penghargaan yang memadai.

Penghargaan yang telah ditetapkan oleh perusahaan tentunya harus dibarengi pula dengan aturan organisasi yang harus ditaati dan dilaksanakan oleh pegawai. Kepatuhan dan juga loyalitas merupakan nilai penting dari sebuah perusahaan dimana, karyawan yang patuh pada ketentuan organisasi tidak akan keluar dari tujuan utama organisasi, dan loyalitas karyawan akan membawa stabilitas pada perusahaan. Dan tentunya apabila aturan organisasi dilanggar, sanksi yang sesuai dan adil harus diberikan.

Sistem penerapan penghargaan dan juga hukuman pada kesalahan. Khususnya kesalahan penerapan sistem penghargaan, akan mengakibatkan turunnya semangat dan kepuasan kerja karyawan, yang apabila terjadi akan mengakibatkan turunnya produktivitas karyawan dan organisasi.

Penerapan reward yang jauh lebih ditonjolkan dibandingkan punishment yang dilakukan olah banyak perusahaan, hal ini memberikan dampak yang sangat baik pada performa karyawan dalam menyelesaikan pekerjaannya. Sebut saja perusahaan yang bergerak di bidang Perbankan, Marketing, Sales dan lainnya yang akan memberikan reward kepada karyawan apabila target penjualan tercapai, baik berupa bonus capaian kinerja, beberapa organisasi bisnis terkemuka di dunia memiliki tingkat sistem penghargaan dan hukuman yang relatif rendah, ini menunjukkan bahwa 
pertumbuhan dan daya saing mereka disebabkan oleh kemampuan unik yang dikembangkan oleh karyawan mereka melalui pengembangan keterampilan tinggi. Menurut FMP Global, reward bisa meningkatkan kesuksesan bisnis hingga $25 \%$. $^{1}$

(Weatherley, 2003) menemukan bahwa sekitar $85 \%$ dari nilai pasar (kinerja) perusahaan dipengaruhi oleh Departemen Sumber Daya Manusianya. Pada kenyataannya, praktik manajemen di tingkat proses organisasi masih jarang memperhatikan peran departemen sumber daya manusia. Perubahan yang semakin kompleks dan tidak terduga dihadapkan dengan perubahan struktural dan budaya, dan perubahan ini terus menekankan investasi nyata, terutama dalam teknologi dan peralatan. Sebuah survei terhadap 54 perusahaan menemukan bahwa karena upaya departemen sumber daya manusia, hanya 51 perusahaan yang tidak mengevaluasi karyawannya (pengukuran kuantitatif) (Ramlall, 2003). Dari 968 perusahaan, kurang dari $10 \%$ memiliki prosedur evaluasi formal untuk mengukur kerja sumber daya manusianya (Brian, Becker E, 2001). Investasi sumber daya manusia berkaitan dengan tingginya biaya yang harus dikeluarkan oleh organisasi, sehingga organisasi memiliki komitmen yang rendah terhadap peningkatan karyawannya.

Banyak sistem penghargaan dan hukuman yang dirancang untuk mempromosikan bisnis, tujuan utama dari rencana penghargaan adalah untuk menarik karyawan yang cakap untuk bekerja di organisasi, mempertahankan kelayakan kerja karyawan dan mendorong karyawan organisasi untuk mencapai kinerja (Gibson, James L., Ivancevich, John M., Donnely Jr., 2000). Reward di definisikan sebagai sebuah Penghargaan dan hukuman dalam situasi kerja, Penghargaan berarti menerima perilaku dan tindakan, dan hukuman berarti menolak tindakan dan perbuatan (Himawan, 2002). Dengan adanya penghargaan dan hukuman diharapkan dapat meningkatkan kinerja karyawan dan memungkinkan perusahaan untuk mencapai tujuan secara keseluruhan.

Pada Penelitian ini berpusat pada Madrasah Ibtidaiyah Sains Baiturrahman Jatinangor sebagai obyek penelitian. Madrasah Ibtidaiyah Baiturrahman merupakan madrasah di bawah kepengawasan Yayasan Baiturrahman Linggajaya, Madrasah berada dilingkungan masyarakat yang Agamis sehingga menyebabkan adanya sosial budaya masyarakat yang agamis dan berpengaruh terhadap pola pikir dan tindakan yang agamis. Hal ini merupakan potensi sosial budaya yang dapat menunjang proses pembelajaran. Madrasah Ibtidaiyah Baiturrahman secara geografis berada di Komplek Linggajaya Desa Mekargalih Kecamatan Jatinangor Kabupaten Sumedang.

Penerapan punishment dan reward di Madrasah Ibtidaiyah Sains Baiturrahman Jatinangor menjadi perhatian penuh bagi pimpinan dan organisasi, untuk memenuhi standart operational di Madrasah Ibtidaiyah Sains Baiturrahman Jatinangor, dan secara aktif berupaya untuk meningkatkan produktivitas pegawai di sektor publik. Ditemukan dalam penelitian beberapa staff yang tidak terbiasa dengan penegakan hukuman dan penghargaan yang ketat mengalami gejala stres, sementara yang lain percaya bahwa ini adalah upaya untuk meningkatkan layanan masyarakat mereka ke Madrasah Ibtidaiyah Sains Baiturrahman Jatinangor.

Berdasarkan hasil observasi awal (Observasi, 2018) yang dilakukan oleh peneliti, terdapat beberapa fenomena yang mengindikasikan bahwa Kinerja pegawai Madrasah Ibtidaiyah Sains 
Baiturrahman Jatinangor cenderung rendah:

a. Pekerjaan yang cenderung monoton dan membosankan

b. Tunjangan yang relative tidak sesuai dengan pekerjaan yang menjadi tanggung jawab masingmasing pegawai

c. Atasan (kepala dinas) yang cenderung tidak memberikan dukungan terhadap pelaksanaan operasional sehari-hari

d. Rekan kerja yang cenderung individualis sehingga tidak bisa melakukan pekerjaan secara tim

e. Banyaknya pegawai yang membolos pada jam kerja, namun pada absen terlihat full, motivasi bekerjanya relative rendah

Beberapa faktor negatif yang dapat menurunkan kinerja pegawai, diantaraNya adalah:

a. Menurunnya keinginan pegawai untuk mencapai prestasi kerja.

b. Kurangnya ketepatan waktu dalam penyelesaian pekerjaan sehingga kurang menaati peraturan.

c. Pengaruh yang berasal dari lingkungannya.

d. Teman sekerja yang juga menurun semangatnya dan tidak ada contoh yang harus dijadikan acuan dalam pencapaian prestasi kerja yang baik.

Berdasarkan uraian diatas menjadi landasan untuk dilakukannya penelitian mengenai "Pengaruh Reward dan Punishment terhadap Kinerja Pegawai (Studi di Madrasah Ibtidaiyah Sains Baiturrahman Jatinangor)".

\section{Tujuan Penelitian}

- Untuk mengetahui Reward, Punishment dan Kinerja

- Untuk mengetahui besarnya Reward dipengaruhi Kinerja
- Untuk mengetahui besarnya Punishment dipengaruhi Kinerja

- Untuk mengetahui Kinerja dipengaruhi secara simultan oleh Reward dan Punishment

\section{TINJAUAN PUSTAKA}

Manajemen Sumber Daya Manusia merupakan salah satu bidang manajemen yang menitik beratkan perhatiannya terhadap masalah-masalah yang berhubungan dengan kepegawaian dalam suatu organisasi atau perusahaan. Oleh karena itu sering juga pengertian Manajemen Sumber Daya Manusia ini disamakan dengan pengertian Manajemen Personalia, karena ruang lingkup yang dipelajari cenderung membicarakan sumber daya manusia dalam organisasi perusahaan.

Menurut (Handoko, 2003) : "Manajemen Sumber Daya Manusia adalah ilmu dan seni atau proses memperoleh, memajukan atau mengembangkan dan memelihara tenaga kerja yang kompeten sedemkian rupa sehingga tujuan organisasi dapat tercapai dengan efisien dan kepuasan pada diri pribadi"

Manajemen sumberdaya manusia menurut Torrington dan Hall (Taufiqurokhman, 2009) "Sejumlah aktivitas yang pertama-tama dapat memungkinkan pekerja dan perusahaan melakukan kesepakatan tentang tujuan dan cara-cara kerja, kedua dapat memastikan persetujuan tersebut terlaksana"

Definisi ini menekankan adanya hubungan kerja yang saling menguntungkan dan bahwa hanya dengan adanya hubungan timbal balik antara individu dan perusahaan, maka tujuan dapat tercapai

Pada dasarnya Manajemen Sumber Daya Manusia (MSDM) merupakan suatu gerakan pengakuan terhadap pentingnya unsur manusia sebagai sumber daya yang cukup potensial, yang perlu dikembangkan sehingga mampu 
memberikan kontribusi yang maksimal bagi organisasi maupun bagi pengembangan dirinya. Hal ini sesuai dengan pendapat dari ahli manajemen Petter dan Waterman dalam bukunya "In search for excellence" yang melaporkan bahwa hasil-hasil penelitian atas perusahaan-perusahaan yang berhasil antara lain; perusahaan itu memperhatikan sumber daya manusianya sedemikian rupa untuk dapat menciptakan pelayanan yang sangat baik untuk pelanggan.

Sumber daya manusia mengacu kepada kebijakan, praktik, dan sistem yang memengaruhi perilaku, sikap, dan kinerja karyawan (Noe, 2021).

Manajemen sumber daya manusia sebagai rencana yang mempengaruhi orang atau karyawan sedangkan Manajemen personalia adalah fungsi yang dijalankan dalam suatu organisasi, yang membantu menggunakan orang (karyawan) secara efektif untuk mencapai tujuan organisasi dan pribadi (John M. Ivancevich, 2010).

Manager sebuah perusahaan dalam melaksanakan kegiatan sumber daya manusia harus memeperhatikan imbas lingkungan eksternal - hukum, politik, ekonomi, sosial, kebudayaan dan teknologi (Robert L. Mathis, John H. Jackson, 2006). Aktivitas tersebut mencakup :

a. Perencanaan dan analisis sumber daya manusia.

b. Peluang pekerjaan yang sama (Equal Employment OpportunityEEO)

c. Pengangkatan pegawai.

d. Pengembangan pegawai.

e. Kompensasi dan tunjangan

f. Kesehatan, keselamatan, dan keamanan.

g. Interaksi karyawan buruh/manajemen.

dan

Dari beberapa pengertian di atas dapat disimpulkan bahwa manajemen sumber daya manusia adalah sebuah rangkaian strategi, proses dan aktivitas yang dirancang untuk menunjang tujuan perusahaan dengan cara mengintegrasikan kebutuhan perusahaan dan individu.

Fungsi-fungsi manajemen sumber daya manusia menurut Dessler (Handoko, 2003) adalah sebagai berikut :

1. Perencanaan

Perencanaan (Human Resources Planning) adalah merencanakan tenaga kerja agar sesuai dengan kebutuhan organisasi dan efektif serta efisien dalam membantu terwujudnya tujuan organisasi.Perencanaan ini untuk menetapkan program kepegawaian yang ada dalam organisasi.

\section{Pengorganisasian}

Pengorganisasian adalah kegiatan untuk mengorganisasi semua karyawan dengan menetapkan pembagian kerja, hubungan kerja, delegasi wewenang, integrasi, dan koordinasinya, dalam bagan organisasi. Organisasi hanya merupakan alat untuk mencapai tujuan. Dengan organisasi yang baik akan membantu terwujudnya tujuan secara efektif.

\section{Pengarahan}

Pengarahan (directing) adalah kegiatan mengarahkan semua karyawan, agar mau bekerjasama dan bekerja efektif serta efisien dalam membantu tercapainya tujuan organisasi, karyawan, dan masyarakat.Pengarahan dilakukan oleh pimpinan dengan kepemimpinannya, memerintah bawahan agar mengerjakan semua tugas-tugasnya dengan baik.

\section{Pengendalian}

Pengendalian (controlling) adalah kegiatan mengendalikan semua karyawan agar mentaati peraturanperaturan organisasi dan bekerja 
sesuai dengan rencana. Bila terdapat penyimpangan atau kesalahan, diadakan tindakan perbaikan dan/atau penyempurnaan rencana.

5. Pengadaan

Pengadaan (procurement) adalah proses penarikan, seleksi, penempatan, orientasi, dan induksi untuk mendapatkan karyawan yang sesuai dengan kebutuhan organisasi. Pengadaan yang baik akan membantu terwujudnya tujuan organisasi.

\section{Pengembangan}

Pengembangan (development) adalah proses peningkatan keterampilan teknis, teoritis, konseptual dan moral karyawan melalui pendidikan dan pelatihan. Pendidikan dan pelatihan yang diberikan, harus sesuai dengan kebutuhan pekerjaan masa kini maupun masa depan.

\section{Kompensasi}

Kompensasi (compensation) adalah pemberian balas jasa langsung (direct) dan tidak langsung (indirect), uang atau barang kepada karyawan sebagai imbalan jasa yang diberikan karyawan kepada organisasi.

\section{Pengintegrasian}

Pengintegrasian (integration) adalah kegiatan organisasi untuk mempersatukan kepentingan organisasi dan kebutuhan karyawan agar tercipta kerjasama yang serasi dan saling menguntungkan.

\section{Pemeliharaan}

Pemeliharaan (maintenance) adalah kegiatan untuk memelihara atau meningkatkan kondisi fisik, mental, dan loyalitas karyawan, agar mereka tetap mau bekerjasama sampai pensiun.
10. Kedisiplinan

Kedisiplinan merupakan fungsi manajemen sumberdaya manusia yang terpenting dan kunci terwujudnya tujuan organisasi, karena tanpa disiplin yang baik sulit terwujudnya tujuan yang maksimal.Kedisiplinan adalah keinginan dan kesadaran untuk mentaati peraturan-peraturan organisasi dan norma-norma sosial.

\section{Pemberhentian}

Pemberhentian (separation) adalah putusnya hubungan kerja seseorang dari suatu organisasi. Pemberhentian ini disebabkan oleh keinginan karyawan, keinginan organisasi, kontrak kerja berakhir, pensiun dan sebab-sebab lain.

(Handoko, 2003) terdapat enam fungsi operatif manajemen sumber daya manusia, yaitu sebagi berikut :

1. Pengadaan tenaga kerja terdiri dari:
a) Perencanaan
sumber daya manusia
b) Analisis jabatan
c) Penarikan pegawai
d) Penempatan kerja
e) Orientasi kerja (Job orientation)

2. Pengembangan tenaga kerja, mencakup :
a) Pendidikan dan pelatihan
b) Pengembangan (karier)
c) Penilaian prestasi kerja

\section{Pemberian balas jasa, mencakup :}

a) Balas jasa langsung terdiri dari : gaji dan upah, insentif.

b) Balas jasa tidak langsung terdiri dari : keuntungan dan pelayanan/ kesejahteraan. 
4. Integrasi, mencakup :
a) Kebutuhan karyawan
b) Motivasi kerja
c) Kepuasan kerja
d) Disiplin kerja
e) Partisipasi kerja

\section{Pemeliharaan tenaga kerja, mencakup :}
a) Komunikasi kerja
b) Kesehatan dan keselamatan kerja
c) Pengendalian konflik kerja
d) Konseling kerja

6. Pemisahan tenaga kerja, mencakup pemberhentian karyawan (PHK).

\section{Reward}

Kata reward berasal dari bahasa inggris yang berarti ganjaran atau hadiah(Echols, John M \& Hasan, 2005). Menurut Irham Fahmi (Fahmi, 2016), reward merupakan bentuk pemberian balas jasa yang diberikan kepada seorang karyawan atas prestasi pekerjaan yang dilakukan, baik berbentuk finansial maupun non finansial.

Reward merupakan sebagai bentuk apresiasi usaha untuk mendapatkan tenaga kerja yang profesional sesuai dengan tuntutan jabatan diperlukan suatu pembinaan yang berkeseimbangan, yaitu suatu usaha kegiatan perencanaan, pengorganisasian, penggunaan, dan pemeliharaan tenaga kerja agar mampu melaksanakan tugas dengan efektif dan efisien (Handoko, 2003). Sebagai langkah nyata dalam hasil peembinaan maka diadakan pemberian reward pegawai yang telah menunjukan prestasi kerja yang baik. Tohardi (2002) menyatakan reward adalah ganjaran yang diberikan untuk memotivasi para karyawan agar produktivitasnya tinggi.

Menurut Nawawi (Nawawi, 2005) "reward adalah usaha menumbuhkan perasaan diterima (diakui) dilingkungan kerja, yang menyentuh aspek kompensasi dan aspek hubungan antara para pekerja yang satu dengan yang lainnya".

Manajer bertugas untuk mengevaluasi hasil kinerja individu baik secara formal maupun informal. Dengan kata lain, reward adalah segala sesuatu yang berupa penghargaan yang menyenangkan perasaan yang diberikan kepada pegawai dengan tujuan agar pegawai tersebut senantiasa melakukan pekerjaan yang baik dan terpuji.

Dalam konsep manajemen, reward merupakan salah satu alat untuk meningkatkan motivasi kinerja para pegawai. Metode ini bisa mengasosiasikan perbuatan dan kelakuan seseorang denga perasaan bahagia, senang dan biasanya akan membuat mereka melakukan suatu perbuatan baik secara berulang - ulang. Reward juga bertujuan agar seseorang menjadi semakin giat dalam usaha memperbaiki atau meningkatkan prestasi yang telah dicapainya.

Manusia selalu mempunyai cita cita, harapan dan keinginan.Inilah yang dimanfaatkan oleh metode reward. Dengan metode ini, seseorang mengerjakan perbuatan baik atau mencapai suatu prestasi tertentu akan diberikan reward yang menarik sebagai imbalan. Dengan demikian, pegawai akan melakukan perbuatan atau mencapai suatu prestasi agar memperoleh reward tersebut.

Reward merupakan alat pendidikan yang mudah dilaksanakan dan sangat menyenangkan para pegawai. Untuk itu reward dalam suatu proses pekerjaan sangat dibutuhkan keberadaannya sebagai motivasi demi meningkatkan kinerja para pegawai. Maksud dari pemberian reward kepada pegawai adalah agar pegawai menjadi lebih giat lagi kerjanya untuk memperbaiki atau mempertinggi prestasi kerja yang telah dicapainya, dengan kata lain pegawai menjadi lebih keras kemauannya untuk meningkatkan kinerjanya. Reward adalah penilaian yang bersifat positif terhadap 
pegawai. Setiap individu atau kelompok yang memiliki kinerja yang tinggi perlu mendapatkan penghargaan (reward).

\section{Punishment}

Kata punishment berasal dari bahasa inggris yang berarti hukuman, sanksi atau siksaan (Echols, John M \& Hasan, 2005) Sedangkan menurut $M$. Ngalim purwanto (Purwanto, 2006) punishment adalah penderitaan yang diberikan atau ditimbulkan dengan sengaja oleh seseorang sesudah terjadi suatu pelanggaran, kejahatan atau kesalahan. Menurut Irham Fahmi (Fahmi, 2016) punishment adalah sanksi yang diterima oleh seorang karyawan karena ketidak mampuannya dalam mengerjakan atau melaksanakan pekerjaan sesuai dengan yang diperintahkan.

Pada dasarnya tujuan pemberian punishment adalah supaya pegawai yang melanggar merasa jera dan tidak akan mengulangi lagi. Dari beberapa pendapat tersebut dapat disimpulkan punishment adalah suatu perbuatan yang kurang menyenangkan yang berupa hukuman atau sanksi yang diberikan kepada pegawai secara sadar ketika terjadi pelanggaran agar tidak mengulangi lagi.

Jika reward merupakan bentuk yang positif, maka punishment adalah sebagai bentuk yang negatif, tetapi kalau diberikan secara tepat dan bijak bisa menjadi alat perangsang pegawai untuk meningkatkan kinerjanya. Tujuan dari metode ini adalah menimbulkan rasa tidak senang pada seseorang supaya mereka jangan membuat sesuatu yang jahat, jadi hukuman yang dilakukan adalah untuk memperbaiki dan mendidik ke arah yang lebih baik.

\section{Kinerja Pegawai}

Para Ahli dalam bidang manajemen memberikan beberapa pandangan yang berbeda terhadap pengertian kinerja berdasarkan perspektif mereka, bahkan berdasarkan pengalaman kerja yang mereka alami dan rasakan secara langsung, pengertian-pengertian kinerja tersebut diantaranya:

Moeheriono (Moeheriono, 2012) kinerja atau performa merupakan gambaran sejauh mana tujuan, sasaran, visi dan misi organisasi yang dijabarkan dalam implementasi rencana aksi atau kebijakan

dalam mewujudkannya dalam perencanaan strategis organisasi.

Produktivitas atau kinerja adalah perilaku nyata yang ditunjukkan setiap orang, karena kinerja karyawan sesuai dengan perannya di perusahaan (Rivai, Veitzaldan Sagala, 2011).

Kinerja adalah pelaksanaan pekerjaan, yaitu hasil dari pelaksanaan rencana kerja yang dirumuskan oleh suatu organisasi, dilaksanakan oleh para manajer dan karyawan (SDM) yang bekerja dalam organisasi tersebut, dan dilaksanakan oleh pemerintah dan perusahaan (perusahaan) untuk mencapai tujuan organisasi (Abdullah, 2014).

Menurut Anwar Prabu Mangkunegara (Mangkunegara Anwar, 2015) dalam bukunya Manajemen Sumber Daya Manusia Perusahaan, mengemukakan pengertian kinerja adalah hasil kerja secara kualitas dan kuantitas yang dicapai oleh seorang karyawan dalam melaksanakan tugasnya sesuai dengan tanggung jawab yang diberikanya.

Kinerja pada dasarnya adalah apa yang dilakukan atau tidak dilakukan oleh karyawan. Mathis dan Jackson (Robert L. Mathis, John H. Jackson, 2006) mengungkapkan bahwa kinerja karyawan yang mempengaruhi seberapa banyak mereka memberikan kontribusi kepada organisasi. Kinerja merupakan hal yang sangat penting dalam suatu perusahaan untuk mencapai tujuannya. Kinerja dapat berjalan baik apabila karyawan mendapatkan gaji sesuai harapan, mendapatkan pelatihan dan 
pengembangan, lingkungan kerja yang kondusif, mendapat perlakuan yang sama, jabatan karyawan sesuai keahliannya serta mendapatkan bantuan perencanaan karir, serta terdapat umpan balik dari perusahaan.

\section{METODE PENELITIAN}

Sebagai variabel independent (variabel bebas) dalam penelitian ini adalah Reward dan Punishment. Sedangkan objek penelitian yang merupakan dependent variabel (variabel tak bebas) adalah Kinerja Pegawai, unsur ini diteliti karena untuk lebih mengetahui secara mendalam mengenai perilaku pegawai di Madrasah Ibtidaiyah Sains Baiturrahman Jatinangor yang berkaitan dengan prestasi kerja/kinerjanya.

Dengan dasar pertimbangan tujuan studi, maka penelitian ini bersifat deskriptif dan verifikatif. Penelitian deskriptif adalah penelitian yang bertujuan untuk memperoleh deskripsi tentang ciri-ciri variabel. Sifat penelitian verifikatif pada dasarnya ingin menganalisa kebenaran dari suatu hipotesis yang dilaksanakan melalui pengumpulan data di lapangan. Mengingat sifat penelitian ini adalah deskriptif dan analisis yang dilaksanakan melalui pengumpulan data di lapangan, maka metode penelitian yang digunakan adalah metode descriptive survey dan metode explanatory survey. Tipe investigasi yang digunakan adalah kausalitas, yaitu tipe penelitian yang menyatakan adanya hubungan sebab akibat antara independent variabel, dalam hal ini Reward dan Punishment terhadap dependent variabel, yaitu Kinerja. Unit analisis dari penelitian ini adalah individu yaitu pegawai di Madrasah Ibtidaiyah Sains Baiturrahman Jatinangor. Dilihat dari time horizon-nya, penelitian ini bersifat cross sectional, yaitu informasi dari sebagian populasi (sampel responden) dikumpulkan langsung di tempat kejadian secara empirik, dengan tujuan untuk mengetahui pendapat dari sebagian populasi terhadap objek yang sedang diteliti.

\section{HASIL PENELITIAN DAN PEMBAHASAN}

Untuk mengungkap pengaruh sebuah variabel atau seperangkat variabel terhadap varibel lain, dapat digunakan Analisis Jalur (Path Analysis). Pada analisis jalur ini besarnya pengaruh suatu variabel terhadap variabel lainnya, baik langsung maupun tidak langsung dapat diketahui. Sebelum mengambil keputusan mengenai besarnya pengaruh suatu variabel terhadap variabel lainnya tersebut, terlebih dahulu dilakukan pengujian hipotesis, baik pengujian secara keseluruhan ataupun secara individual.

Untuk mengetahui apakah varibel bebas yaitu Pengaruh reward dan Punishment terhadap kinerja pegawai di Madrasah Ibtidaiyah Sains Baiturrahman Jatinangor, dilakukan dengan menggunakan analisis jalur (path analysis) dan software yang digunakan adalah SPSS release 12.

\section{Pengaruh Reward Terhadap Kinerja Pegawai Madrasah Ibtidaiyah Sains Baiturrahman Jatinangor}

Berdasarkan hasil perhitungan , maka dapat terungkap bahwa Reward terhadap kinerja pegawai di Madrasah Ibtidaiyah Sains Baiturrahman Jatinangor baik secara langsung maupun tidak langsung dapat terlihat bahwa kontribusi reward terhadap kinerja pegawai secara langsung sebesar $27.33 \%$ dengan koefisien thitung sebesar 2.817, sedangkan untuk nilai tabel pada taraf signifikansi $\alpha(0,05)=1.67$, karena nilai thitung $>$ tabel, serta tidak langsung melalui variabel Punishment sebesar $6.89 \%$. Sedangkan kontribusi reward terhadap kinerja pegawai secara keseluruhan mencapai $64.22 \%$, dapat disimpulkan bahwa 
reward signifikan berpengaruh langsung terhadap kinerja, bukti empiris ini memberikan indikasi bahwa dalam upaya meningkatkan kinerja pegawai, perlu adanya perbaikan faktor paradigma reward, karena faktor reward terkait erat dengan peningkatan kinerja. Koefisien jalur menunjukkan nilai positif dan signifikan, artinya dimana semakin baik reward yang diberikan kepada pegawai, maka kinerja pegawai akan meningkat.

\section{Pengaruh Punishment Terhadap Kinerja Pegawai Madrasah Ibtidaiyah Sains Baiturrahman Jatinangor}

dapat terlihat bahwa kontribusi Punishment terhadap kinerja pegawai secara langsung sebesar $17.19 \%$ dengan koefisien thitung sebesar 1.241, sedangkan untuk nilai tabel pada taraf signifikansi $\alpha(0,05)=1.67$, karena nilai thitung $>$ tabel, serta tidak langsung melalui variabel reward sebesar $6.89 \%$. Sedangkan kontribusi Punishment terhadap kinerja pegawai secara keseluruhan mencapai $24.08 \%$, dapat disimpulkan bahwa Punishment signifikan berpengaruh langsung terhadap kinerja pegawai, bukti empiris ini memberikan indikasi bahwa dalam upaya meningkatkan kinerja pegawai, perlu adanya perbaikan faktor Punishment, karena faktor Punishment terkait erat dengan peningkatan kinerja pegawai. Koefisien jalur menunjukkan nilai positif dan signifikan, artinya dimana semakin baik penerapan sistem Punishment akan memperbaiki kinerja pegawai.

\section{Pengaruh Reward dan Punishment $\begin{array}{llr}\text { Terhadap } & \text { Kinerja } & \text { Pegawai } \\ \text { Madrasah } & \text { Ibtidaiyah } & \text { Sains } \\ \text { Baiturrahman Jatinangor } & \end{array}$}

Dari hasil pengujian dapat diketahui bahwa Reward dan Punishment berpengaruh terhadap kinerja pegawai di Madrasah Ibtidaiyah Sains Baiturrahman Jatinangor yakni sebesar $58.5 \%$, sedangkan sisanya sebesar $41.5 \%$ dipengaruhi oleh faktor-faktor lain yang tidak diteliti oleh penulis yaitu iklim kerja, komitmen, budaya kerja, lingkungan kerja. Namun apabila dilihat secara parsial Reward dominan mempengaruhi kinerja pegawai daripada Punishment, dari hasil pengujian hipotesis terlihat bahwa reward dominan mempengaruhi kinerja pegawai dengan koefisien jalur sebesar 0.376 dengan thitung sebesar 2.817 dengan nilai tabel pada taraf signifikansi $a(0,05) \quad=1.67$, daripada Punishment sebesar 0.226 dengan thitung sebesar 1.241 dengan nilai trabel pada taraf signifikansi $\alpha(0,05)=1.67$, serta kedua variabel tersebut terbukti mempengaruhi kinerja pegawai

\section{KESIMPULAN DAN SARAN}

\section{Kesimpulan}

Berdasarkan hasil penelitian yang telah dilakukan untuk mengetahui Pengaruh Reward dan Punishment Terhadap Kinerja Pegawai pada Madrasah Ibtidaiyah Sains Baiturrahman Jatinangor, maka dapat ditarik kesimpulan sebagai berikut :

1. Pegawai di Madrasah Ibtidaiyah Sains Baiturrahman Jatinangor beranggapan bahwa reward yang diterima secara keseluruhan sudah sesuai harapan, hanya dengan ssitem kompensasi saat ini ternyata banyak pegawai yang beranggapan bahwa reward yang diterima masih jauh dari harapan. Hal ini terlihat dari indikator memperhatikan kesejahteraan karyawannya dan memberikan pelatihan atau seminar terhadap pegawainya masih perlu ditingkatkan dan diperbaiki kedepannya, karena rata-rata pegawai menganggap dua hal tersebut masih buruk dan belum sesuai harapan.

2. Secara keseluruhan Punishmentyang diterima pegawai di Madrasah Ibtidaiyah Sains Baiturrahman Jatinangor sudah tergolong baik, hanya dengan ssitem kepemimpinan 
saat ini ternyata banyak pegawai yang beranggapan bahwa punishment yang diterima masih jauh dari harapan. Hal ini tercermin dari indikator kepemimpinan yang memberikan peringatan kepada yang melanggar disiplin kerja atau karakteristik pelayanan yang tidak memenuhi standar ketenagakerjaan; manajemen memberikan sanksi yang berat kepada karyawan yang melanggar aturan dan disiplin kerja, dan manajemen memberikan peringatan berupa Surat Peringatan (SP) yang menunjukkan hasil rendah dimana rata-rata pegawai menganggap ketiga hal tersebut masih buruk dan belum sesuai harapan yang diakibatkan adanya sistem kedekatan yang terjadi diantara pimpinan dan pegawai sehingga ada perbedaan perlakuan yang dilakukan oleh pimpinan.

3. Kinerja Pegawai di Madrasah Ibtidaiyah Sains Baiturrahman Jatinangor secara Keseluruhan sudah baik, akan tetapi dari 6 indikator yang digunakan, terdapat 4 indikator yang nilainya rendah, yakni paham dengan pekerjaan yang menjadi tanggung jawab; memiliki rencana untuk menyelesaikan pekerjaan yang menjadi tanggungjawabnya mengetahui standar operasional pada institusi Madrasah Ibtidaiyah Sains Baiturrahman Jatinangor; Hasil pekerjaan yang telah di selesaikan seusia dengan perintah pimpinan dan Jumlah pekerjaan yang telah diselesaikan sesuai dengan target. Hal ini mengindikasikan bahwa pegawai di Madrasah Ibtidaiyah Sains Baiturrahman Jatinangor belum menunjukkan kinerja yang sesuai dengan harapa organisasi.

4. Reward dan Punishment secara simultan berpengaruh terhadap kinerja pegawai di Madrasah lbtidaiyah Sains Baiturrahman Jatinangor serta pengaruhnya positif.
Namun secara parsial Reward dominan mempengaruhi kinerja pegawai daripada Punishment. Dan secara parsial, pengaruh Reward dan Punishment terhadap kinerja adalah sebagai berikut:

a. Reward berpengaruh terhadap kinerja pegawai, sehingga apabila Reward yang diterima pegawai sesuai dengan harapannya, maka kinerja pegawai akan meningkat pula.

b. Punishment berpengaruh terhadap kinerja pegawai, sehingga apabila Punishment yang diberikan sesuai, maka kinerja pegawai akan meningkat pula.

\section{Saran}

Berdasarkan hasil penelitian dan pengamatan yang telah dilakukan, maka penulis ingin mengajukan beberapa saran yang dapat dijadikan pertimbangan bagi Madrasah Ibtidaiyah Sains Baiturrahman Jatinangor. untuk meningkatkan Reward dan Punishment. Saran-saran tersebut antara lain

1. Perbaikan reward di Lingkungan Madrasah Ibtidaiyah Sains Baiturrahman Jatinangor, dimulai dari memperhatikan kesejahteraan karyawannya. Madrasah Ibtidaiyah Sains Baiturrahman Jatinangor memberikan pelatihan atau seminar terhadap pegawainya, maka mereka akan mengetahui standar operasional yang ditetapkan di sekolah.

2. Perbaikan pemberian Punishment di Madrasah Ibtidaiyah Sains Baiturrahman Jatinangor harus segera di lakukan, sebab dengan sistem kepemimpinan saat ini ternyata banyak pegawai yang beranggapan bahwa punishment yang diterima masih jauh dari harapan. Untuk menanggulanginya maka dimulai dari pimpinan memperingatkan yang melanggar 
disiplin kerj, dan karakteristik yang tidak memenuhi standar ketenagakerjaan yang tak sesuai dengan standar operasional kerja tidak terlepas pada pegawai yang mana saja atau tidak pandang bulu, sehingga tidak ada kesenjangan social. Pimpinan harus bisa memberikan surat peringatan (SP) yang merupakan teguran berat bagi siapa saja pegawai yang melanggar ketentuan Madrasah Ibtidaiyah Sains Baiturrahman Jatinangor..

3. Perbaikan mengenai Kinerja Pegawai di Madrasah Ibtidaiyah Sains Baiturrahman Jatinangor secara Keseluruhan dimulai dari perbaikan paham pegawai mengenai pekerjaan yang menjadi tanggung jawabnya, menumbuhkan rasa keinginan untuk memiliki perencanaan untuk menyelesaikan pekerjaan yang menjadi tanggung jawabnya, memberikan sosialisasi agar pegawai mengetahui standar operasional dalam institusi Madrasah Ibtidaiyah Sains Baiturrahman Jatinangor, perbaikan terkait hasil pekerjaan yang telah di selesaikan sesuai dengan perintah pimpinan tidak memakan waktu yang banyak serta jumlah pekerjaan yang diselesaikan harus sesuai dengan target yang telah ditetapkan.

4. Prioritas yang harus diperhatikan oleh Madrasah Ibtidaiyah Sains Baiturrahman Jatinangor dengan mengoptimalkan Sistem pemberian Punishment agar tercipta kinerja yang premium.

5. Variabel yang tidak di teliti oleh penulis : iklim kerja, komitmen, budaya kerja dan lingkungan kerja.

\section{DAFTAR PUSTAKA}

Abdullah. (2014). Manajemen dan Evaluasi. A swaja Pressindo.

Brian, Becker E, M. A. . \& D. (2001). The HR Score Card: Linking People,
Strategy and Performance (B. Massachusetts (ed.)). Hardvard Bussiness School Press.

Echols, John M \& Hasan, S. (2005). Kamus Inggris Indonesia. Gramedia Pustaka Utama.

Fahmi, I. (2016). Teori dan Teknik Pengambilan Keputusan. Raja Grafindo Persada.

Gibson, James L., Ivancevich, John M., Donnely Jr., J. H. (2000). Organisasi dan Management (4th Editio). Erlangga.

Handoko, T. H. (2003). Manajemen Sumber Daya Manusia (Jilid 2). BPFE.

Himawan, H. (2002). Kinerja Kantor Pertahanan dan Studi Kasus Proses Pelayanan Sertifikat Tanah di Kantor Pertanahan Kota Pekanbaru. Universitas Gajah Mada.

John M. Ivancevich. (2010). Human Resource Management. McGrawHill, N ew York, 4.

Mangkunegara Anwar, P. (2015). Manajemen Sumber Daya Manusia. Remaja Rosdakarya.

Moeheriono. (2012). Pengukuran Kinerja Berbasis Kompetensi. Grafindo Persada.

Nawawi, H. (2005). Manajemen Sumber Daya Manusia. Gadjah Mada.

Noe, R. A. (2021). Human Resource Management, Gaining a Competitive Advantage. McGraw-Hill, New York, 5.

Purwanto, N. (2006). IImu Pendidikan Teoritis dan Praktis. Remaja Rosdakarya.

Ramlall, S. J. (2003). Measuring Human Resource Management Effectiveness in Improving Performance, Human Resource Planning. In Measuring Human Resource Management Effectiveness in Improving Performance, Human Resource 
Planning. (Volume 26, pp. 51-77).

Rivai, Veitzaldan Sagala, E. J. (2011).

Manajemen Sumber Daya Manusia

untuk Perusahaan dari Teori ke

Praktik. Raja Grafindo Persada.

Robert L. Mathis, John H. Jackson, D. A. (2006). Human Resource Management. 10th Editi, 43-44.

Taufiqurokhman. (2009). Mengenal Manajemen Sumber Daya Manusia. Fakultas IImu Sosial dan IImu Politik Universitas Prof. Dr. Moestopo Beragama.

Tohardi, Ahmad. 2002. Pemahaman Praktis Manajemen Sumber Daya Manusia. Bandung : Mandar Baru

Weatherley, L. . (2003). The Value of People: The Challanges and Opportunities of Human Capital Measurement and Reporting. (Research Q). 